\title{
FORMATION AND IMPROVEMENT OF ORGANIZATIONAL AND ECONOMIC BASES OF FORESTRY PRODUCTION IN STATE FORESTRY IN UKRAINE AND PODILLIA REGION
}

\author{
O. Yaremko \\ $\mathrm{PhD}$ in Economics \\ Ternopil Regional Department of Forestry and Hunting \\ (Ternopil, Ukraine) \\ e-mail: OYaremko@i.ua \\ ORCID: https://orcid.org/0000-0003-4619-0527
}

\begin{abstract}
Some issues on the historical formation of Podillia region of modern Ukraine and the formation of forestry in it are covered. It practically begins and acquires social meaning in the second half of the twentieth century. This means the use of land provided to economic entities (forestries) for growing wood as their main forestry product. The same applies to the cultivation and sale of natural resources related to forestry, secondary forest materials, services of various contents, etc. It is highlighted that the Forest Code of Ukraine has cunningly replaced the object of labor and use of the natural resource "Earth" with forest resources. The issues are somewhat complicated by the use of tax indicators and forms of their analysis and publication without their adaptation to the UN-ECE / FAO Standard Statistical Classification of Land Use and without the necessary grouping by forest and environmental components. The Government of Ukraine approves the Resolution "On Approval of the Procedure for Division of Forests into Categories and Allocation of Specially Protected Forest Areas», which does not bring national forest legislation closer to it. In this way, the further growth of non-timber forest lands at least 3 times or more in comparison with the leading European countries was legitimized.

The necessity of improving the content of the current Forest Code of Ukraine, as well as finalization and updating of the Instruction on forest management in the state forestry of Ukraine is proved. The availability of statistical and reporting information on the state of forests of the State Forest Agency of Ukraine for state-owned enterprises of the past allows to update the relevant reporting indicators while adapting them to the norms of European forestry. The proposed measures are aimed at improving forest legislation, as well as the formation of measures in the practical activities of forest management and the work of managers using its materials in forestry.
\end{abstract}

Keywords: forest lands, code, forest ecosystems, forestry, forest use, division, forestry production.

\section{INTRODUCTION}

Podillia (Podilska land, Lowlands, Transnistria, and Pobuzhye) is a historical and geographical region of Ukraine, covering the territory of modern Vinnytsia, Khmelnytskyi (without the northern strip), Ternopil (south), northern districts of Odesa regions, as well as small adjacent territories of Zhytomyr, Cherkasy, Kirovohrad and Kyiv regions. Podilska land also includes northern Transnistria [1].

For the first time, the name "Podillia» is used in documents of the 14th century. Historians and ethnographers divide Podillia into East and West. There is a reasoned opinion: in the early $1320 \mathrm{~s}$ as a result of another attack of the horde on the Galicia-Volyn principality, southern Bessarabia (between the Prut and the Dniester north of the Danube) and the Galician Lowlands became part of the Golden Horde, forming Podolsk land.

The active development of the region and the construction of fortified castles began after the conquest by Olgerd, the Grand Duke of Lithuania, in 1362 at the latest, as a result of which the land became part of the Grand Duchy of Lithuania-Russia (GDL) with its center in Vilno (Vilnius). The region of Podillia (Podolia) was the first mark on the map in 1491. According to the same source, the map was engraved on copper in the city of Eichstedt (Germany). A historical region in the central-western part of Ukraine, occupying the basin of the interfluve of the Southern Bug and the left tributaries of the Dniester. Podillia combines picturesque natural and historical monuments. These are the Kamianets-Podilskyi fortress in the middle of the Smotrytsky canyon, the flooded village of Bakota, as well as the town-peninsula of Zalishchyky in the bowl of the canyon on the Dniester (fig. 1).

The availability of land in Podillia for utilization and development has contributed, in particular, to a reduction in the area of land covered by forest vegetation due to population growth, 
Formation and improvement of organizational and economic bases of forestry production in state forestry in Ukraine and Podillia Region

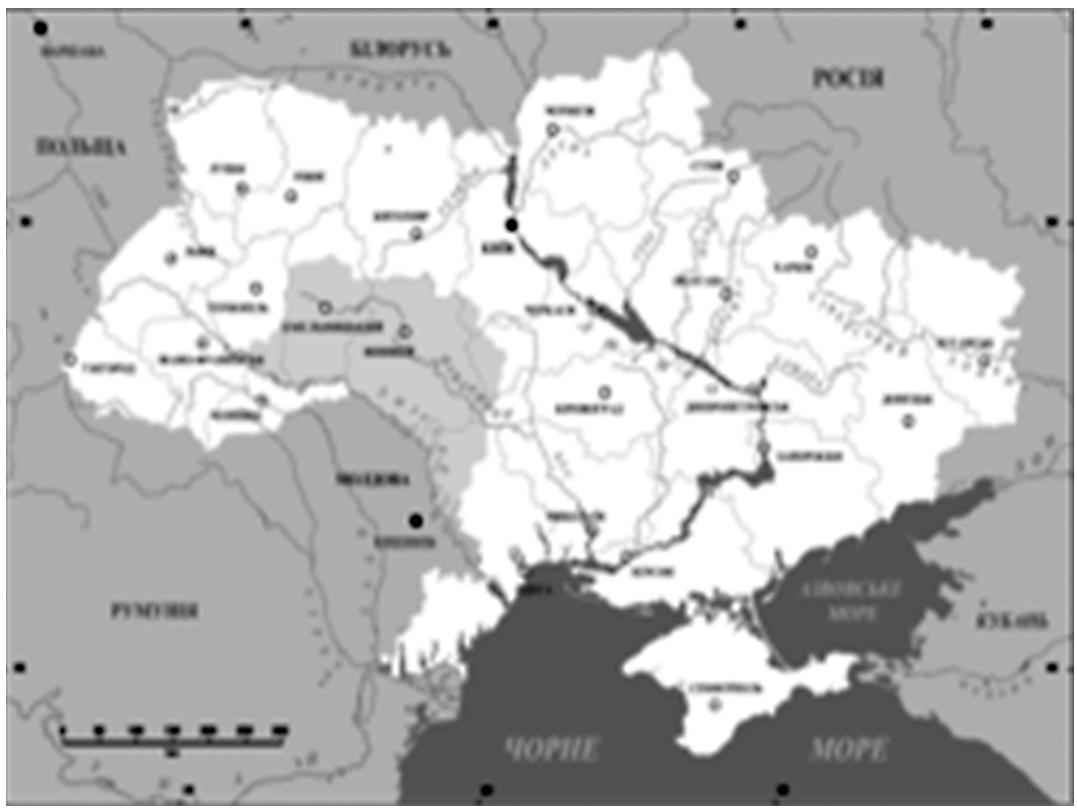

Fig. 1. Podillia region on the map of Ukraine Source: [1].

the development of agriculture and trade, and the growing need for new agricultural land.

Historical data show: "The production of potash, which began in Ukraine at the end of the 15 th century and quickly spread to Volyn, Podillia, Kyiv and Chernihiv regions, was devastating for the forest. In the middle of the 17 th century, potash was extracted from wood on the territory of the Right Bank of Ukraine, Galicia, and Zakarpatti» [2].

\section{Recent era}

After the defeat of the Ukrainian national liberation struggles of 1917-1921, part of the lands of Podillia became part of the Ukrainian SSR. On the territorial basis of Eastern and Western Podillia, there was Podolsk province (abolished by the resolution of the All-Ukrainian Central Executive Committee of June 3, 1925). In 1932 the Vinnytsia region was created, and on September 22, 1937 - by the resolution of the CEC of the USSR - Kamianets-Podilskyi with the center in the city of Kamyanets-Podilsky and Zhytomyr regions of the USSR.

The region has an extensive railway infrastructure. The 78-kilometer-long HaivoronRudnytsia narrow-gauge railway passes through this territory. A historical region in the centralwestern part of Ukraine, occupying the basin of the interfluve of the Southern Bug and the left tributaries of the Dniester.

Part of Western Podillia along the Zbruch River in 1921-1939 was part of Poland. As a result of the annexation of the territories of Poland and Romania in 1939-1940, the entire territory of Podillia became part of the regions of the Ukrainian SSR.

In 1941-1944, the territory of Podillia was divided between the German General Province, the General District of Volyn-Podillia and the General District of Zhytomyr, and the Romanian Governorate of Transnistria. Today, the geographical area of Podillia, according to Wikipedia, is about 61 thousand $\mathrm{km}^{2}$, population - about 4.6 million people. Thus, the territory of Podillia region is more than 6 million hectares or $10.1 \%$ of the total area of the country (table 1).

The table below shows the area by region, the boundaries of which, of course, do not fully coincide with the limits of the natural and ecological region «Podillia». Because some of its shares, as mentioned above, are in the neighboring districts of the Odesa region, as well as small adjacent areas of Zhytomyr, Cherkasy, Kirovohrad, and Kyiv regions.

It so happened that the land area of these 3 regions is also $10.1 \%$ of the country's territory. This makes it acceptable to use them to analyze the condition and ways of developing forestry production in the region of Podillia of Ukraine. It is fair to say that the structure and directions of properly organized state forestry in Podillia region were established on a joint basis in 1945 and persist to this day. It is the longest in comparison with the past medieval petty princely wars, incl with the Tatar invasion of the 13 th century and the Nazi conquerors of 1941-1945. Eventually, 
Division of the area of Podillia region by regions, Recent era

\begin{tabular}{|l|c|c|}
\hline \multicolumn{1}{|c|}{ Regions } & $\begin{array}{c}\text { Area, } \\
\text { thousand hectares }\end{array}$ & $\begin{array}{c}\text { Share } \\
\text { to total area, \% }\end{array}$ \\
\hline Vinnytsia & 2649,2 & 4,4 \\
\hline Ternopil & 1382,4 & 2,3 \\
\hline Khmelnytskyi & 2062,9 & 3,4 \\
\hline Together & 6094,5 & 10,1 \\
\hline The total area of the country & 60354,8 & 100,0 \\
\hline The area of the region according to Wikipedia is $61 \mathrm{~km}^{2}$ & 6100 & 10,1 \\
\hline
\end{tabular}

Source: [2;8].

with the accession of the western Ukrainian lands to the Ukrainian SSR, the development of state forestry as a branch of crop production based on forest management materials begins, sustainable development and experience of Western European, Russian and Ukrainian schools of forestry, forestry norms, and rules, forest use.

It is also important that today, according to official sources, in these areas there is a legal consolidation of the right to use forest lands, including the accounting category of land use «Forest lands».

The object of research: forest relations from the definition of the term «Forest» as land covered with forest vegetation or intended for this purpose, to forest use - the extraction of wood from forest ecosystems for income, as well as the production of forest materials, with the restoration of forest ecosystems.

The aim of the work: to update the used meaning of the terms «Forest» and «Forestry production» of the state forestry of Ukraine, their dependence on technological and political changes to improve the regional organization of forestry production on the principles of a market economy and taking into account the tasks of the Land Reform of 1990.

\section{ANALYSIS OF RECENT RESEARCH AND PUBLICATIONS}

Problematic issues regarding the formation and improvement of organizational and economic bases of forestry production have been studied in the works of leading scientists Bobko A., Furdychka O., Drebot O., Shershun M., Sinyakevycha I., Antonenko I., Koval J., and others. The works of these leading scientists reflect research that contributes to the development of scientific understanding of the solution of the problems of the organization of forestry production in general.

It should be noted that the issues of imperfection of forest legislation have been widely researched and discussed in sectoral and national sources of information. For example, in the journal «Economy of Ukraine», the editorial board of which inclined to publish research on forestry production, reported: "The system of land and forest legislation of Ukraine on the taxation of forest lands as the main natural resource used in the process of forestry is flawed, which requires the introduction of payment for land» [17, p. 24].

\section{MATERIALS AND RESEARCH METHODS}

Analysis of forestry terms and their content, condition, and use of land resources provided to enterprises of the State Forestry Agency of Ukraine according to the legal requirements for the right of permanent use, used as a productive force for the organization of forestry production. At the same time, in contrast to the previous experience of forestry, in connection with the intention of Ukraine to join the European Union, is based on the Standard Statistical Classification of Land Use established by the UN-ECE / FAO [3].

The methodological component of the study consists of the provisions of the economics of nature management and environmental protection, the forest sector, as well as scientific works of domestic and foreign scientists and personal research. Research methods: system approach and analysis, historical, monographic, economicstatistical, system-structural and graphic.

\section{RESULTS AND DISCUSSION}

1. The term "forest» as defined by the Forest Code of Ukraine and its comparison with European legislation

The beginning of the formation of the national forest legislation coincides with the adoption of the Verkhovna Rada of Ukraine resolution «On land reform» as well as with the political decision of the state on Ukraine's accession to 
Formation and improvement of organizational and economic bases of forestry production

in state forestry in Ukraine and Podillia Region

the European Union. All of them have necessitated significant changes in numerous NPAs regarding land use, forest use, land taxation, and their adaptation to European legislation. But it so happened that in the Forest Code of Ukraine, the relevant rules were often «adapted» to the legislation of the former USSR or set out in any form, with their misreading, difficult to understand and apply the content.

For example, the Polish Law on Forests of September 28, 1991 states: "A forest within the meaning of the Law is land» [4]. Quite different is written in the Forest Code of Ukraine: «Forest - a type of natural complexes (ecosystem), which combines mainly woody and shrubby vegetation...» [5]. If the tax indicator of Poland's «Forest - land» is its physical area used to calculate the amount of the annual tax on land, then the Ukrainian «Forest - a type of natural complexes» in the calculation of taxes in the practice of Ukrainian state forestry is not used.

One can imagine that this is not done to complicate the understanding of the meaning of the term «forest use». Just editorial error. But according to Article 17 of the Forest Code of Ukraine, it acquires, frankly, entrepreneurial content. For permanent use «forests on stateowned lands for forestry without a deadline are provided to specialized state forestry enterprises, other state enterprises, institutions and organizations in which specialized forestry divisions have been established» [5]. Apparently, the object of labor was replaced, and the productive force of the natural resource «Earth» which provided to forestries by forest resources. More precisely, the products of forestry production and the right of specialized state forestry enterprises (SFE) dispose of all forest and other resources, i.e. products of state forestry. Let's think about it: specialized FEs are not even former forest enterprises but full owners of all forest resources and the natural environment of the enterprise. In addition, without paying land tax for the use of all land and financial income. Although the main norm of European legislation in the implementation of forestry is the payment for the land. In addition, depending on its productivity, with the assessment of land by quality classes for indigenous forest-forming species. From here, the indicator of «rational use and protection of land» [6], defined by the Land Reform in Ukraine, should be calculated.

Therefore, the definition of the term «Forest» and its description established by the UN-ECE / FAO as land not accepted in Ukrainian legislation. Hence the numerous inconsistencies between them, which have a purely entrepreneurial orientation and are widely used to form a variety of corrupt structures for wood extraction. Forestry entities do not take into account the requirements for transparency of financial and economic information about their production activities. As a result, none of the enterprises in the industry reports on the efficiency of economic activity for each financial year, including by indicators «Income» «Expenses» «Net income» as it was in the early twentieth century.

Organized forestry production in Ukraine originated, as is known from literary sources, somewhere in the middle of the XIX century, is associated with the establishment of the Forest Department in the Russian Empire (1798). At the same time, there is a transition from valdmeysterstva, the ability to use forest resources, to forstmeysterstva, ie the ability to grow forest (wood). Since then, the object of work in the state forests is not forest resources, of which wood was the absolute dominant, but land, land resources legally intended for forestry and «proper forest management».

We will remind that this coincided to some extent in Ukraine with the beginning of the socalled General Land Use Survey in the 18th century, granting land ownership and the right to use, according to the government manifesto of 1765. The activities continued until the end of the 19th century, as they required the training of relevant scientific institutions and specialists in geodesy, cartography, forest assessment, etc. Of course, the objects of cartography, hence the assessment and accounting, were land plots, with properly defined boundaries in kind, fixed by state signs of the established form and the corresponding appointment.

Since FORESTS (more precisely — forests), by definition, V.I. Dalia, "It is a space covered with trees growing and plants» at that time they had a corresponding distribution and were often simply inaccessible, such lands remained in state ownership. For the organization within their limits of the arranged forestry according to Western European content, the formation of including state forestry began in Ukraine. It acquires special development after the establishment of the above-mentioned Forest Department and its regional bodies in the Ukrainian provinces - Kyiv, Poltava, South-West and Polissya, etc.

Distributed recently in Ukraine judgments about that «The value of forests as ecosystems is incomparable with the benefits that can be derived from the sale of timber» [18] is somewhat emotional and entrepreneurial. To some extent, without understanding the philosophical interpretation of the law, «everything flows and everything changes». In the field of forestry, this law is the most noticeable and the main feature 
of its agro-environmental content. Land and its biological productivity are of unsurpassed value for forestry. Forestry, of any modification and subordination, to which land provided for the implementation of forestry, are clearly and above all land users.

Thus, in modern terms, the essence of forestry production is to ensure the full and most rational use of land, legally granted by the authorities to forestry entities for growing forests as their main commodity products, as well as its implementation to obtain forest income, forestry and other types of production, the population, etc. Numerous water protection, protective, sanitary, health, recreational, aesthetic, educational, other functions, advertised by the Forest Code of Ukraine, are functionally related and depend only on the art of management and accumulation of timber in forest plantations. They are not subject to differential division by distribution.

It is also known historically that «since 1842 , forest management has been carried out in the state forests of several provinces by the person of the Instruction, drawn up on the Western European model» [19]. Since then, forestry science has accumulated numerous studies on forest taxation and forest management, which ensured the introduction of "proper forestry", the organization of forest use, ie the extraction of wood from stands for the production of forest materials from it, taking into account the market demand for them and based on the current state of forest ecosystems, permanent reforestation.

However, before the proclamation of Ukraine's independence, in the practice of forest management and state accounting of forests, the term, and category of reporting «State Forest Fund» was maintained, so to speak, by inertia. Although, of course, state accounting and reporting concerned the categories of land use.

Thus, the object of labor and management, a sign of organizational and economic management in forestry, becomes a plot of land covered with forest vegetation or intended for this purpose, identified by the legal definition of public authorities.

The effectiveness of such a system in the field of state forestry in Ukraine and other former Soviet republics proved indisputably. Evidence of this is the presence in Ukraine and Podillia forests, as well as statistical and accounting information about their area, systematically accumulated from the second half of the twentieth century to the present.

After all, the basics of state forestry production in the regions of Podillia and other regions of Ukraine, despite the numerous transformational processes of territorial and political change, cur- rently created, need improvement and development taking into account the experience of European and national forestry on issues within the legal land use.

2. The content of the organizational and economic division of land resources, its accounting, and division by purpose

Regarding the internal economic division of land use by accounting categories for the last year of state accounting (2011), we should note some connection with its inconsistency with the above-mentioned UNECE/FAO Standard Statistical Classification of Land Use, as well as the national Instruction on land accounting [7]. The corresponding table has 27 columns and is not very acceptable for use, does not agree with either European or national accounting. Their improvement and harmonization need fundamental clarifications.

Thus, taking into account the scientific research and conclusions of IAEP NAAS of Ukraine, we used proposals to update their land use accounting for environmental components within the State Forest Resources Agency of Ukraine and the regions of Podillia (table 2) [8]. It should be noted at once that the former category of land use in forestry "Non-forest lands» is united by us under the name "Lands of other accounting categories» because according to the UN-ECE / FAO GCC, the category of land use "Non-forest lands» does not exist. In addition, they all have slight dissemination (for UAVs of Ukraine $-7.6 \%$, in Podillia - $2.8 \%$ ) and any measures within their non-forestry production.

This form is consistent with the UNECE /FAO GCC and national standards. Reference to the Report on Land Accounting Forms approved by the Ministry of Regional Development of Ukraine, inappropriate. After all, industry counts of Form 16-ZEM and others proposed and conducted by the State Forestry Agency of Ukraine taking into account the peculiarities of sectoral production and the need for rational use of land for forestry. Counts 19-21 of the administrative reporting are described so wordily and contradictorily, that it is almost impossible to understand and apply them correctly. For example, in count 20 : «Forest land plots not covered with forest vegetation» indicates the area of forest land plots, permanently or temporarily not covered by forest vegetation (due to the heterogeneity of forest natural complexes, forestry activities or natural disasters, etc.), in particular, forest areas occupied by open forest crops, forest nurseries, and plantations ... « [9], etc.

The principles of adaptation of normative legal acts to the EU legislation are established by the Law «On the National Program of Adaptation 
Formation and improvement of organizational and economic bases of forestry production

in state forestry in Ukraine and Podillia Region

General characteristics of forestry lands of Podillia region of Ukraine by basic and forestry-ecological categories of land use as of January 1, 2011

\begin{tabular}{|c|c|c|c|c|c|c|c|c|}
\hline \multirow[b]{4}{*}{$\begin{array}{l}\text { Areas of Podillia } \\
\text { region }\end{array}$} & \multicolumn{8}{|c|}{ The total area of land for forestry purposes, thousand hectares } \\
\hline & \multicolumn{7}{|c|}{ Including forest land } & \multirow{3}{*}{ 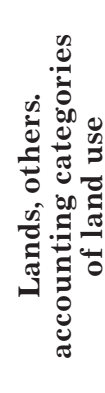 } \\
\hline & & \multicolumn{6}{|c|}{ By environmental components } & \\
\hline & Total & Total & 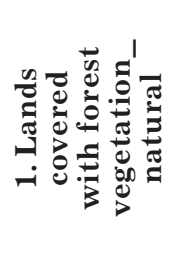 & 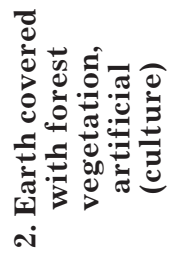 & 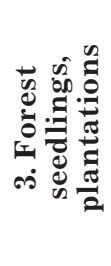 & 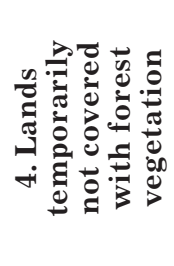 & 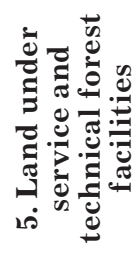 & \\
\hline $\mathbf{A}$ & 1 & 2 & 3 & 4 & 5 & 6 & 7 & 8 \\
\hline $\begin{array}{l}\text { The State Forest } \\
\text { Resources Age- } \\
\text { ncy of Ukraine }\end{array}$ & 7402,3 & 6840,4 & 3050,2 & 3447,1 & 14,6 & 220,3 & 108,1 & 561,9 \\
\hline Share, \% & 100 & 92,4 & 41,2 & 46,6 & 0,2 & 3,0 & 1,5 & 7,6 \\
\hline Vinnytsia & 214,0 & 209,9 & 58,9 & 145,5 & 0,8 & 1,4 & 3,3 & 4,1 \\
\hline Ternopil & 156,9 & 153,4 & 51,8 & 96,1 & 0,7 & 1,9 & 2,9 & 3,5 \\
\hline Khmelnytskyi & 185,2 & 177,5 & 49,7 & 121,6 & 0,6 & 3,3 & 2,3 & 7,7 \\
\hline Total & 556,1 & 540,8 & 160,4 & 363,2 & 2,1 & 6,6 & 8,5 & 15,3 \\
\hline Share, \% & 100,0 & 97,2 & 28,8 & 65,3 & 0,4 & 1,2 & 1,5 & 2,8 \\
\hline
\end{tabular}

Source: [8].

of the Legislation of Ukraine to the Legislation of the European Union». Law of Ukraine of March 18, 2004, № 1629-IV as amended [10]. It, in particular, provides for the Cabinet of Ministers of Ukraine:

3) to ensure that ministries and other central executive bodies bring their regulations in line with this Law. The section "General Provisions» provides: «The purpose of adapting the legislation of Ukraine to the legislation of the European Union is to achieve compliance with the legal system of Ukraine acquis communautaire taking into account the criteria set by the European Union (EU) for the countries that intend to join it « $[10]$.

In practice, it turned out quite differently. The mentioned Law of Ukraine was adopted in 2004, and in 2007 the Resolution of the Cabinet of Ministers was issued «On approval of the Procedure for division of forests into categories and allocation of specially protected forest areas» which in European legislation does not exist... Incidentally, the above EU system «acquis communautaire taking into account the criteria set by the European Union (EU) to the states that intend to join it «is necessarily the norm. Therefore, the approval of the Procedure for the division of forests into categories and the allocation of specially protected forest areas is inappropriate [11] (table 3 ). Contains 4 accounting categories of the first level. In addition, it contradicts common sense and the above principle «acquis communautaire». Not to mention that three of them were further divided into lower-level categories.

In addition, there is no such classification in European forestry. It would be acceptable to divide forests into categories established by the UN-ECE/FAO (2000). The ECE/FAO sets a deadline "Wood supply» in the sense of: "Wood for extraction - systematic extraction of individual trees from forest ecosystems or within local areas to use it for industrial production of timber, taking into account market demand and forestry norms and rules, as well as to rejuvenate forest ecosystems and improve their ecological status « [12]. This would divide the forest lands into only two categories (table 3 ) instead of 4 categories of the first level and more than ten in their composition of the lower level.

According to the description, for example, the accounting category «Forests not intended for timber extraction and production of forest materials» its formalization at the state level 
Division of forest lands and forests by categories of their economic purpose in relation to felling of the main use

\begin{tabular}{|l|l|l|}
\hline \multicolumn{1}{|c}{ o } & $\begin{array}{c}\text { Categories of ECE forest } \\
\text { accounting by economic } \\
\text { purpose }\end{array}$ & \multicolumn{1}{c|}{$\begin{array}{c}\text { Description of accounting categories as defined } \\
\text { by UN-ECE/FAO of the UN }\end{array}$} \\
\hline \hline 1. & $\begin{array}{l}\text { Forests are designed to } \\
\text { extract timber and forest } \\
\text { materials production }\end{array}$ & $\begin{array}{l}\text { Forests where any legal, economic or special environmental } \\
\text { restrictions do not have a significant effect on timber extracti- } \\
\text { on. Includes Forest lands, where there are no such restrictions, } \\
\text { but the removal of wood not carried out, for example, in areas } \\
\text { included in certain long-term plans or intentions. }\end{array}$ \\
\hline 2. & $\begin{array}{l}\text { Forests not intended for } \\
\text { timber extraction and } \\
\text { forest materials production }\end{array}$ & $\begin{array}{l}\text { Forests where legislative, economic, or special environmental } \\
\text { restrictions prevent any significant removal of wood. Includes } \\
\text { Forest with legal restrictions or restrictions arising from other } \\
\text { policy decisions, which completely exclude or significantly } \\
\text { limit the offer of wood, including the reasons for the preser- } \\
\text { vation of ecological or biological diversity, for example, forest } \\
\text { protection, national parks, nature reserves. }\end{array}$ \\
\hline
\end{tabular}

Source: formed by the author on the basis [12].

is not covered, in Ukraine, it is allegedly «developed» by the Government [11]. Because the issue is solved mainly by the main forestry subjects of forestry production together with managers of local authorities and environmental organizations. As a result, the volume of timber extraction from forest ecosystems («deforestation» in the Ukrainian discourse) in the developed countries of Europe occupies limited distribution (tab. 4).

For the practice of Ukrainian state forestry (the State Forest Resources Agency of Ukraine) and further adaptation to EU forestry production, their classification in the category «Forests not for timber extraction and forest materials production» are 3 times smaller in comparison with Ukraine (36.6\% of all forest lands). In Germany $-5.6 \%$, neighboring Hungary $-6.0 \%$ and so on. For the State Forest Resources Agency of Ukraine, this can and should become a state task of the State Enterprise of Forestry for the next $3-5$ years, to bring their share to $10-12 \%$. The table contains the content: «Distribution of the area covered with forest vegetation on stands, possible for operation and excluded from the calculation of fellings of the main use» [13].

Ideologically and practically, such a name contains a significant inaccuracy. After all, the taxonomic description... «lands covered with fo-

Table 4

Division of forest lands (forests) by economic categories of accounting of individual EU countries according to the EEC / FAO (2000)

\begin{tabular}{|c|c|c|c|c|}
\hline \multirow{2}{*}{ Countries } & \multicolumn{2}{|c|}{$\begin{array}{l}\text { Forests are designed to extract timber } \\
\text { and forest materials production }\end{array}$} & \multicolumn{2}{|c|}{$\begin{array}{l}\text { Woods not to extract timber and forest } \\
\text { materials production }\end{array}$} \\
\hline & $\begin{array}{c}\text { Total, } \\
\text { thousand hectares }\end{array}$ & $\begin{array}{l}\text { Share from } \\
\text { «Forest lands», \% }\end{array}$ & $\begin{array}{l}\text { Total, } \\
\text { thousand hectares }\end{array}$ & $\begin{array}{c}\text { Share from } \\
\text { «Forest lands», \% }\end{array}$ \\
\hline Austria & 3352 & 87,3 & 488 & 12,7 \\
\hline Bulgaria & 3124 & 87,0 & 466 & 13,0 \\
\hline Germany & 10142 & 94,4 & 598 & 5,6 \\
\hline Hungary & 1702 & 94,0 & 109 & 6,0 \\
\hline Poland & 8300 & 92,8 & 642 & 7,2 \\
\hline Slovakia & 1706 & 84,6 & 310 & 15,4 \\
\hline Switzerland & 1060 & 90,4 & 113 & 9,6 \\
\hline Ukraine & 5999 & 63,4 & 3459 & 36,6 \\
\hline Sum & 35385 & 85,1 & 6185 & 14,9 \\
\hline
\end{tabular}

Source: formed by the author on the basis [13, p. 66-67]. 
Formation and improvement of organizational and economic bases of forestry production

in state forestry in Ukraine and Podillia Region

rest vegetation and intended for these purposes» are constantly changing, and the definition of the term «forest» includes both lands covered with forest vegetation and other components of forest ecosystems.

Meanwhile, the directory of the forest fund of Ukraine on January 1, 2011, contains a table "Distribution of the area of forest areas covered with forest vegetation into stands, possible for operation and excluded from the calculation of felling for the main use « [8, p. 60-61]. Very intricate description. Although it all comes down to reducing the transparent extraction of timber, despite the development of forestry and logging, forestry activities are based on a market economy - payment for land, self-sufficiency, and profitability of forestry production.

To fully understand the need to adapt the terms and definitions of Ukrainian forest legislation to the legislation of the EU, we note that the current «Procedure for the division of forests into categories and the allocation of specially protected forest areas» [11] — this is an «achievement» that does not exist in European forestry. According to European regulations, there is a category of accounting «Forests intended for timber extraction and forest materials production « as well as «Forests not intended for timber extraction and forest materials production «. The first category includes accounting in the Ukrainian forestry «Operational forests». «Recreational and health forests» (2) and "Protective forests» (3) are conditionally classified as «Forests not intended for timber extraction and forest materials production». That is their use for timber extraction and production of forest materials is quite limited for environmental, political, religious, or other reasons.

Please note that in a country which is the ancestor of the implementation of forestry both scientifically justified use of land for growing forests, out of 10 million hectares, only $5.6 \%$ of the land (598 thousand hectares) not intended for growing wood for the production of forest materials (see table 4). In the Ukrainian state forestry from the area of lands of 6 million hectares, 36,6\% of them (3,5 million hectares) referred to those that «are not intended for the extraction of wood and forest materials production». This is a clear example of the fallacy of scientific and technical management in the state forestry. After all, the object of work in forestry is the land, not just the land covered with forest vegetation.

After all, the object of work in forestry is the land, not just the land covered with forest vegetation. Growing and extraction of wood for its realization for production of forest materials a basis of bases for forestry production. The con- stant spread of areas of the category «Forest Lands», designed for growing forests and sale of timber to the subjects of logging and timber production and forest industrial production the basis of forestry production (FP) of any business entity in the field of forestry.

This is confirmed by the indicator "share of Forest Lands in the total area, \%» within the accounting category «Forests intended for the extraction of wood and production of Forest Materials» similar division in the forests of the SFRA and the region of Podillia (table 5). According to the State Forest Resources Agency of Ukraine, the share of forest lands intended for the cultivation and sale of wood for the production of forest materials is $58.4 \%$. This is the lowest rate in comparison with the leading countries of European forestry (see table 4).

At the same time, the beginning of that erroneous path to economic and efficient use of land as a productive force, «Formation of a diversified economy, rational use and protection of lands» was provided by the Land Reform proclaimed in 1990. Without identification of economic entities, the issue of assessing the rational use of forest lands for forestry production should begin for each of the forestries. The issue of ecological and economic importance in comparing the division of forests by content as a forest ecosystem and relevant components justified by IAEM of NAAS of Ukraine. They are in all respects more rational for characterizing the state of use of Forestry lands and for elaboration of further measures for the development of FP.

Please note that in the regions of Podillia region «Lands covered with forest vegetation artificial» that is, culture, which occupies $67.2 \%$ (by the State Forest Resources Agency of Ukraine $50.4 \%$ ) of the area of the region. The latter creates conditions and opportunities for finding and creating more productive wood species. This creates conditions and opportunities for finding and creating tree species, necessary for the gradual development of forestry as a crop, more productive, taking into account the growth of promising demand for forest materials by the subjects of logging production and woodworking industry.

First of all, regional demand, taking into account the increase in jobs, etc.

Thus, the implementation of the internal economic division of land resources in forest management is not free, although it should be carried out strictly in the order established by the Instruction on forest management of forestry lands and concerns the most important regulation of the volume of timber extraction from forest ecosystems to rejuvenate the forest, provide raw materials for logging and wood- 
Possible for timber extraction and production of timber and Forests are not intended for timber extraction in Ukraine and oblasts within Podillia region according to the forest management of the State Forest Resources Agency of Ukraine (2011)

\begin{tabular}{|l|c|c|c|c|c|}
\hline \multirow{2}{*}{ Regions } & \multicolumn{2}{|c|}{$\begin{array}{c}\text { The total area } \\
\text { of land covered with } \\
\text { forest vegetation }\end{array}$} & $\begin{array}{c}\text { Forests are designed to extract } \\
\text { timber and forest materials } \\
\text { production }\end{array}$ & $\begin{array}{c}\text { Forests are not designed to extract } \\
\text { timber and forest materials } \\
\text { production }\end{array}$ \\
\cline { 3 - 6 } & & $\begin{array}{c}\text { Total, } \\
\text { thousand } \\
\text { hectares }\end{array}$ & $\begin{array}{c}\text { Share from } \\
\text { «Forest lands», } \\
\text { \% }\end{array}$ & $\begin{array}{c}\text { Total, } \\
\text { thousand } \\
\text { hectares }\end{array}$ & $\begin{array}{c}\text { Share from } \\
\text { «Forest lands», \% }\end{array}$ \\
\hline \hline Ukraine & $\mathbf{1}$ & $\mathbf{2}$ & $\mathbf{3}$ & $\mathbf{4}$ & $\mathbf{6}$ \\
\hline & $\mathbf{6 2 9 3 , 5}$ & $\mathbf{3 6 7 5 , 9}$ & $\mathbf{5 8 , 4}$ & $\mathbf{2 6 1 7 , 7}$ & $\mathbf{4 1 , 6}$ \\
\hline Vinnytsia & \multicolumn{2}{|c|}{ Including by regions of Podillia region } & & \\
\hline Ternopil & 199,9 & 160,8 & 80,4 & 39,1 & 19,6 \\
\hline Khmelnytsky & 143,6 & 99,4 & 69,2 & 44,2 & 30,8 \\
\hline Total & 166,2 & 125,7 & 75,6 & 40,5 & 24,4 \\
\hline
\end{tabular}

Source: [8].

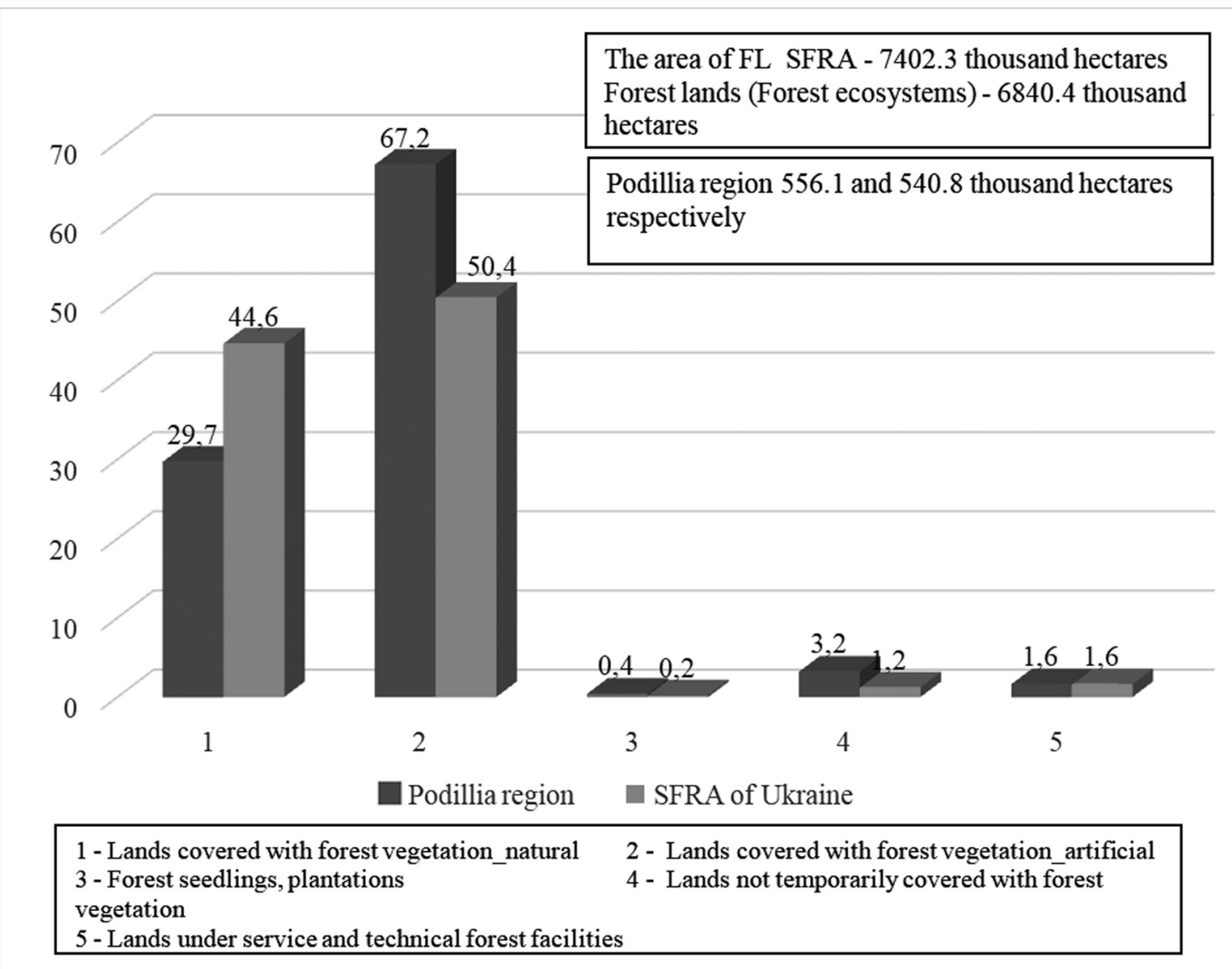

Fig. 2. Comparison of components of forest ecosystems of SFRA of Ukraine of enterprises of Ukraine with enterprises of Podillia region, \%

Source: [8]. 
Formation and improvement of organizational and economic bases of forestry production

in state forestry in Ukraine and Podillia Region

working, requires significant improvement and transparent formalization on the principles of a market economy.

3. The question of the formation of the organizational and economic division of lands as a part of the state forestry production

The choice of organizational and economic objects is the most important but, at the same, time the most complex part of the mechanisms of using forest lands for growing forest. The difficulty manifested in the fact that modern managers of practical forestry and forest management work with already operating parts, including the leading tax indicators, their names, etc. Specialists need time to implement in their imagination the changes that have taken place and are taking place in the political system of the country, related to the transition of Ukraine's economy to market principles: land use identification, cost recovery, and profitability.

Since the times of centralized state forest management, depersonalized by forestry entities, The Forest Code of Ukraine includes one and a half dozen normative legal acts, which are entrusted to the Cabinet of Ministers of Ukraine. In the conditions of reforming the national economy of Ukraine, the management of LGV enterprises must form its activities and responsibilities for the results of the use of land resources, especially on the cultivation and sale of timber for harvesting forest materials. Not only in terms of descriptive content but with quantitative and qualitative indicators of changes in the composition of administratively subordinated land.

At one time, there were norms in forestry regarding the constant introduction of current changes in forest management materials and forest bookkeeping books. If the last inventory of the forest fund was made on January 1, 2011, involuntarily there is an opinion that such changes are not made by specialists of state forestries. Distributed annual reporting materials on the results of the work of enterprises of the SFRA of Ukraine have a fragmentary content of the achievements, for example, on the creation of forests, without covering changes in their area at the beginning and end of the current reporting year.

The latter, to some extent, indicates the absence of fixed volumes for some of the most important tax indicators throughout the LGV chain, from forestry as its primary organizational and economic cell. One of them, taking into account the changes in the accounting of land resources, there is a column «Forest and another wooded land» (erroneous translation from English «Forests and other wooded lands» as defined by the UN-ECE/FAO). There is no such term in the annual reporting materials of the SFRA. There is also no column for the category of land use accounting for «Forestry assignment lands (FAL)». In the directory as of January 1, 2011, it is entitled «Distribution of forest lands fund» indicators of which determine the total land-use area for all accounting categories of land use of the Standard Statistical Classification of the EU and the National Accounting System [3; 8].

After all, as is well known, since the time of the provincial zemstvos, all land users have submitted a report on land use annually, indicating the area of «Forests», «Shrubs» in the field of forestry. Even a comparison in terms of «Revenue» «Expenses» «Net income». Although the cultural and educational level of forestry training has increased considerably, the means and methods of calculation have significantly improved, but there is no acceptable initial information on land accounting and timber extraction from forest ecosystems for the production of forest materials in Ukraine and within its regions for The Central Executive Bodies have no practice.

Previously, there are instructions on making changes to the forms of accounting of the Forest Fund in the order of current activities gradually, probably, were forgotten. They have not been restored since Ukraine's independence. Today it has the official status of the Directory of the Forest Fund of Ukraine on January 1, 2011. And its name should be slightly different. For example, the Handbook on the status and use of the accounting category of land use "Lands of forestry purpose».

However, the Handbook does not contain taxonomic indicators for the distribution of forest lands, including the most important of them indicators of distribution by «Types of forest vegetation conditions». Although it is needed by forestry management to assess compliance grown forest by main forest-forming species, calculation of tax liabilities, payment of land tax, assessment of land use rationality.

Historically, it is known that measures to limit the extraction of wood aimed at protecting forests along large rivers, given their water regulation and conservation value. In practice, from the beginning, the division into two groups of forests is formed, guided by the principles of access to forests, as well as taking into account the protection of natural complexes. Subsequently, the relevant state (approved by the state) norms are disseminated, crushed, and so on. As a result, already in recent times, in 2007, the Cabinet of Ministers of Ukraine approves the «updated» above-mentioned «The procedure for dividing forests into categories and allocating specially protected forest areas». We emphasize that the 
division is not land, but forests, but forests, although we are talking about the category of accounting «Forest lands».

This is even though prominent managers of state forestry wrote back in 1994 «... Today, the basis of forestry organization is a cumbersome, detached system of dividing forests into groups and categories, as well as numerous prohibitions and restrictions, which are largely contrary to the nature of forestry and management objectives» [14]. Why no one heard (read) them, few people know.

The abandonment of the traditional organization of well-known economic parts and economic sections has led to the mechanical filling of the relevant columns, without linking them to the actual forestry production. Thus, the table «Distribution of forest plots by forest categories, economic parts, farms, economic sections, and dominant breeds» in the project of organization and development of forestry occupies $11 \mathrm{pa}-$ ges. Including at the same time, for example, economic sections with an area of 0.2 hectares - $\mathrm{Ca}-$ nadian poplar and white willow; 6.0 hectares Crimean pine; 4.5 hectares - Austrian pine; 0.4 ha - birch bark, etc., which have neither scientific nor practical meaning as independent objects for the organization of LGV [15, p. 5869 ]. Some kind of green Pseudotsuga (0.1 ha), or Menzis Pseudotsuga (1.2 ha), can make sense in a garden or park, or botanical garden...

It is worth recalling that forestry as a branch of crop production «Engaged in growing forests to produce wood» [16, p. 422]. This is its main economic purpose. Such a task should be performed primarily by the project of organization and development of forestry of any state forestry enterprise.

For a general idea of the Forest indicator established by the UNECE/FAO, here is its definition translated from English: A forest is land with an area of more than 0.5 ha with trees exceeding 5 meters and a crown cover of more than 10 percent, or trees capable of reaching these thresholds in situ» [12]. Notice the description in English «in situ», which means "on the site of growth», i.e. within the site, taking into account the types of forest vegetation conditions (FVC). Within the «in situ» is determined by the native forest species, as well as the expected quality class, that is necessary to ensure the accounting of land tax for the use of land resources. Practice and normative principles in the state forestry of Ukraine do not practice this.

After all, the formation of the organizational and economic division of land as part of the state forestry production in forest management during independence has been postponed, in most cases, since the time of the state centralized forest management, without taking into account the new requirements and directions defined by the tasks of Land and Economic reforms, with the transition of forestry management to market principles.

\section{CONCLUSIONS}

Given that, so to speak, the foundation for forestry in the state forestry there is the Forest Code of Ukraine, first of all, it is urgently necessary:

1) make clarifications and changes to the adaptation of its terms and criteria (indicators) to the legislation of the European Union to achieve compliance of the legal system in state forestry with the principles «Acquis communautaire» "Nominated by the European Union (EU) to States intending to join it»;

2 ) to update the content of the Instruction on forest management in the state forestry of Ukraine, with a description of the relevant terms and their measurements, with the participation of leading industry scientists and research institutions of the NAS of Ukraine, NAAS of Ukraine by its proper formation and approval at the state level;

3) consider, as a pilot project, the possibility of forming a local region in Ukraine within Podillia for development on separate state forestry enterprises of projects of the organization and development of forestry, taking into account the proposals of IAEM of NAAS of Ukraine on the accounting of land resources by components of forest ecosystems;

4) to update the relevant assessment indicators for forest assessment as part of the State Forestry according to their state accounting on 01.01 .1988 , on 01.01 .2002 , and 01.01 .2011 , a simultaneous adaptation of terms to the norms of European forestry.

\section{REFERENCES}

1. Podillia [Podillya]. ULR:https://uk.wikipedia.org/wiki/\%D0\%9F\%D0\%BE\%D0\%B4\%D1\%96\%D0\%BB\% $\mathrm{D} 0 \% \mathrm{BB} \% \mathrm{D} 1 \% 8 \mathrm{~F}$ [in Ukrainian].

2. Gensiruk, S.A., Furdychko, O.I. \& Bondar, V.S. (1995). Istoriia lisivnytstva v Ukraini: navch. posib. History of forestry in Ukraine: tutorial]. Lviv: Svit [in Ukrainian].

3. Standard classification of land use UN-ECE/FAO. (1989). Developed and approved by the Statistical 
Formation and improvement of organizational and economic bases of forestry production

in state forestry in Ukraine and Podillia Region

Commission and the European Economic Commission». Conference of European Statisticians. Thirtyseventh plenary session, Geneva, Switzerland, 12-16 June [in English].

4. O lasach: Ustawa z dnia 28 werzsnia 1991 r. Nr 101 poz. 444. Kancelaria Seimu. ULR: https://isap.sejm. gov.pl/isap.nsf/DocDetails.xsp?id=WDU19911010444 [in Polish].

5. Lisovyi kodeks Ukrainy [the Forest Code of Ukraine]. (1994). Vidomosti Verkhovnoi Rady Ukrainy - Information from the Verkhovna Rada of Ukraine. ULR: https://zakon.rada.gov.ua/laws/show/385212\#Text [in Ukrainian].

6. Pro zemelnu reformu: Postanova Verkhovnoi Rady Ukrainskoi RSR vid 18 hrudnia 1990 roku № $563-$ XII iz zminamy vid 22.09.2005 r. [On land reform: Resolution of the Verkhovna Rada of the Ukrainian SSR on December 18, 1990 № 563-XII as amended on September 22, 2005]. (1990). ULR: https://zakon. rada.gov.ua/laws/show/563-12 [in Ukrainian].

7. Instruktsiia z zapovnennia derzhavnoi statystychnoi zvitnosti z kilkisnoho obliku zemel: Nakaz Derzhavnoho komitetu statystyky Ukrainy vid 05.11.98 № 377 [Instructions for filling in the state statistical reporting on quantitative land accounting : Order of the State Statistics Committee of Ukraine dated 05.11.98 № 377]. (1998). ULR: http://zakon2.rada.gov.ua/laws/show/z0788-98 [in Ukrainian].

8. Dovidnyk Lisovoho fondu Ukrainy za materialamy derzhavnoho obliku lisiv stanom na 01.01 .2011 roku [Handbook of the Forest Fund of Ukraine on the materials of state forest accounting as of 01.01.2011]. (2012). Irpin: State Agency of Forest Resources of Ukraine. Ukrainian State Design and Production Association [in Ukrainian].

9. Instruktsiia iz zapovnennia formy administratyvnoi zvitnosti z kilkisnoho obliku zemel (forma № 16-zem (richna)): Nakaz Ministerstva rehionalnoho rozvytku, budivnytstva ta zhytlovo-komunalnoho hospodarstva Ukrainy vid 30.12.2015 № 337 [Instructions for filling in the form of administrative reporting on quantitative land accounting (form № 16-land (annual)): Order of the Ministry of Regional Development, Construction and Housing of Ukraine dated 30.12.2015 № 337]. (2015). ULR: https://zakon. rada.gov.ua/laws/show/z0136-16\#Text [in Ukrainian].

10. Pro Zahalnoderzhavnu prohramu adaptatsii zakonodavstva Ukrainy do zakonodavstva Yevropeiskoho Soiuzu: Zakon Ukrainy vid 18 bereznia 2004 roku № 1629-IV iz zminamy [On the National Program of Adaptation of the Legislation of Ukraine to the Legislation of the European Union: Law of Ukraine of March 18, 2004 № 1629-IV as amended]. (2004). ULR: https://zakon.rada.gov.ua/laws/show/162915\#Text [in Ukrainian].

11. Pro zatverdzhennia Poriadku podilu lisiv na katehorii ta vydilennia osoblyvo zakhysnykh lisovykh dilianok: Postanova KMU vid 16 travnia 2007 r. № 733 [On approval of the Procedure for division of forests into categories and allocation of specially protected forest areas: Resolution of the Cabinet of Ministers on May 16, 2007 № 733]. (2007). ULR: http://zakon4.rada.gov.ua/laws/show/733-2007-ח [in Ukrainian].

12. Global Forest Resources Assessment (FRA). URL: https://en.wikipedia.org/wiki/Global_Forest_Resources_Assessment_(FRA) [in English]

13. Forest resources of Europe, CIS, North America, Australia, Japan and New Zealand. (2000). UN-ECE/ FAO. New York and Geneva [in English].

14. Brezhniev, V.M. (1994). Lisove pravo — pidvalyny novykh ekonomichnykh vidnosyn [Forest law — the foundation of new economic relations]. Lisovyi zhurnal - Forest magazine, 5, 3 [in English].

15. Proiekt orhanizatsii ta rozvytku lisovoho hospodarstva Derzhavnoho pidpryiemstva "Ternopilskyi lishosp» [Project of organization and development of forestry of the State Enterprise "Ternopil Forestry»]. (2014). Lviv [in Ukrainian].

16. Hensiruk, S.A. (1999). Ukrainska entsyklopediia lisivnytstva [Ukrainian encyclopedia of forestry]. Lviv [in Ukrainian].

17. Bobko, A. (2010). Ekonomichni aspekty zemlekorystuvannia u lisivnytstvi Ukrainy ta shliakhy yoho vdoskonalennia [Economic aspects of land use in forestry of Ukraine and ways to improve it]. Ekonomika Ukrainy - Ukraine economy, 11, 14-25 [in Ukrainian].

18. Iukhnovskyi, I.R. (2003). Lisove hospodarstvo Ukrainy: problemy ta perspektyvy [Forestry of Ukraine: Problems and prospects]. Kyiv: DUS [in Ukrainian].

19. Kozlovskiy, B.A. (1959). Kratkie svedeniya po razvitiyu dorevolyutsionnogo lesoustroystva. Vsesoyuznoe aerofotolesoustroitelnoe ob'edinenie "Lesproekt» [Brief information on the development of pre-revolutionary forest management. All-Union aerial photo forest management association «Lesproekt»]. Moscow [in Russian]. 


\title{
ФОРМУВАННЯ Й УДОСКОНАЛЕННЯ ОРГАНІЗАЦИЙНО-ГОСПОДАРСЬКИХ ОСНОВ ЛІСОГОСПОДАРСЬКОГО ВИРОБНИЦТВА В ДЕРЖАВНОМУ ЛІСІВНИЦТВІ В УКРАЇНІ ТА РЕГІОНУ ПОДІЛЛЯ
}

\author{
О.П. Яремко \\ кандидат економічних наук \\ Тернопільське обласне управління лісового і мисливського господарства \\ e-mail: OYaremko@i.ua; \\ ORCID: https://orcid.org/0000-0003-4619-0527
}

Висвітлені окремі питання з історичного бормування Поділъсъкого регіону сучасної України та бормування в нъому лісівництва. Воно, практично, розпочинаєтъся $i$ набуває суспільного змісту з другої половини ХХ століття. Мається на увазі використання наданих земельних угідь суб'єктам господарювання (лісгоспи) для вирошування деревини як головної їхнвї продукиії лісівництва. Те ж стосується вирощування та реалізаиї супутніх лісівництву природних ресурсів, другорядних лісових матеріалів, послуг різного змісту тошо. Висвітлено, шо Лісовим кодексом України лукаво проведена підміна об' єкта праиі й використання природного ресурсу “Земля» лісовими ресурсами. Питання дещо ускладняються застосуванням таксаційних показників $i$ форм їх аналізу та оприлюднення без їх адаптації до Стандартної статистичної класифікацїі землекористування СЕК/ФАО ООН $і$ без необхідного їх угрупування за лісівничо-екологічними компонентами. Урядом України затверджуєтъся Постанова «Про затвердження Порядку поділу лісів на категорії та виділення особливо захисних лісових ділянок», яка ніяк не наближає національне лісове законодавство до нъого. У такий спосіб легітимували подальше зростання земель лісових, не призначених для вилучення деревини, щуонайменше в 3 рази й більше у порівнянні з провідними європейсъкими країнами.

Доведена необхідність удосконалення змісту чинного Лісового кодексу України, а також доопрацювання $і$ актуалізаиї Інструкиї з лісовпорядкування в державному лісівниитві України. Наявність статистичної $і$ звітної інбормаиї про стан лісів Державного лісового агентства України по державних підприєлствах минулої пори дозволяє провести актуалізаиію відповідних звітних показників з одночасною їх адаптаиією до норм європейсъкого лісівництва. Запропоновані заходи спряловані на удосконалення лісового законодавства, а також на борлування заходів у практичній діяльності з лісовпорядкування та роботи менеджерів із використанням його матеріалів у лісогосподарсъкому виробництві.

Ключові слова: землі лісогосподарсъкого призначення, кодекс, лісові екосистеми, лісове господарство, лісокористування, поділ, лісогосподарсъке виробництво.

\section{ЛITEPATУРA}

1. Поділля. ULR: https://uk.wikipedia.org/wiki/\%D0\%9F\%D0\%BE\%D0\%B4\%D1\%96\%D0\%BB \%D0\%BB\% D1\%8F (дата звернення: 08.07.2021).

2. Генсірук С.А., Фурдичко О.І., Бондар В.С. Історія лісівництва в Україні: навч. посіб. / за ред. С.А. Генсірука. Львів: Світ, 1995. 424 с.

3. Standard classification of land use UN-ECE/FAO. Розроблена і затверджена Статистичною комісією та Європейською економічною комісіями. Конференція європейських статистиків. Тридцять сьома пленарна сесія. ЖЖенева, 12-16 червня 1989 р.

4. Про ліси: Закон від 28 вересня 1991 р. № 101 ст. 444. Канцелярія Сейму. ULR: https://isap.sejm.gov. pl/isap.nsf/DocDetails.xsp?id=WDU19911010444 (дата звернення: 08.07.2021).

5. Лісовий кодекс України. Відомості Верховної Ради України (ВВР). 1994. ULR: https://zakon.rada. gov.ua/laws/show/3852-12\#Text (дата звернення: 09.07.2021).

6. Про земельну реформу: Постанова Верховної Ради Української РСР від 18 грудня 1990 року № $563-$ XII із змінами від 22.09.2005 p. ULR: https://zakon.rada.gov.ua/laws/show/563-12 (дата звернення: 11.07.2021)

7. Інструкція з заповнення державної статистичної звітності з кількісного обліку земель: Наказ Державного комітету статистики України від 05.11.98 № 377. Державний комітет України по земельних peсурсах. ULR: http://zakon2.rada.gov.ua/laws/show/z0788-98 (дата звернення: 12.07.2021).

8. Довідник Лісового фонду України за матеріалами державного обліку лісів станом на 01.01.2011 року. Ірпінь: Державне агентство лісових ресурсів України. Українське державне проектно-виробниче об'єднання, 2012. 130 с.

9. Інструкція із заповнення форми адміністративної звітності з кількісного обліку земель (форма № 16-зем (річна)): Наказ Міністерства регіонального розвитку, будівництва та житлово-комунального господарства України від 30.12.2015 № 337. Департамент містобудування, архітектури та планування територій. ULR: https://zakon.rada.gov.ua/laws/show/z0136-16\#Text (дата звернення: 12.07.2021). 
Formation and improvement of organizational and economic bases of forestry production

in state forestry in Ukraine and Podillia Region

10. Про Загальнодержавну програму адаптації законодавства України до законодавства Європейського Союзу: Закон України від 18 березня 2004 року № 1629-IV із змінами. ULR: https://zakon.rada.gov. ua/laws/show/1629-15\#Text (дата звернення: 13.07.2021).

11. Про затвердження Порядку поділу лісів на категорії та виділення особливо захисних лісових ділянок: Постанова КМУ від 16 травня 2007 р. № 733. ULR: http://zakon4.rada.gov.ua/laws/show/7332007-п (дата звернення: 13.07.2021).

12. Global Forest Resources Assessment (FRA). URL: https://en.wikipedia.org/wiki/Global_Forest_Resources_Assessment_(FRA) (дата звернення: 13.07.2021).

13. Forest resources of Europe, CIS, North America, Australia, Japan and New Zealand. UN-ECE/FAO. New York and Geneva, 2000. pp. 66-67.

14. Брежнєв В.М. Лісове право — підвалини нових економічних відносин. Лісовий журнал. 1994. № 5. C. 3 .

15. Проєкт організації та розвитку лісового господарства Державного підприємства «Тернопільський лісгосп». Львів, 2014. 326 с.

16. Генсірук С.А. Українська енциклопедія лісівництва. Львів, 1999. С. 422.

17. Бобко А. Економічні аспекти землекористування у лісівництві України та шляхи його вдосконалення. Економіка України. 2010. № 11. С. 14-25.

18. Юхновський I.P. Лісове господарство України: Проблеми та перспективи. Київ: ДУС, 2003.177 с.

19. Козловский Б.А. Краткие сведения по развитию дореволюционного лесоустройства. Всесоюзное аэрофотолесоустроительное объединение «Леспроект». Москва, 1959. С. 42-48.

\section{ВІДОМОСТІ ПРО АВТОРА}

Яремко Олег Павлович, кандидат економічних наук, начальник Тернопільського обласного управління лісового і мисливського господарства (м. Тернопіль, Україна; e-mail: OYaremko@ i.ua; ORCID: https://orcid.org/0000-0003-4619-0527).

\section{HOBHAH}

$\mathrm{B}$ ерховна Рада України у другому читанні підтримала законопроект, який підвищує штрафри за випалювання рослинності в екосистемах. За проект 3526 на засіданні проголосували 311 депутатів. Законопроект вносить зміни до Водного кодексу, Кодексу цивільного захисту, Земельний кодекс і Кодекс про адміністративні правопорушення. 